\title{
SERUM URATE CONCENTRATIONS IN THE AUSTRALIAN ABORIGINAL
}

\author{
BY
}

\author{
B. T. EMMERSON, ${ }^{1}$ W. DOUGLAS, ${ }^{1}$ R. L. DOHERTY, ${ }^{2}$ AND P. FEIGL ${ }^{3}$
}

From the University of Queensland Department of Medicine at Princess Alexandra Hospital, Brisbane, Queensland, ${ }^{1}$ the Queensland Institute of Medical Research, Brisbane, ${ }^{2}$ and the Johnson Research Foundation of the University of Pennsylvania School of Medicine, Philadelphia ${ }^{3}$

Studies of indigenous Pacific peoples have often revealed populations with a high incidence of gout or with mean serum urate concentrations signifcantly higher than Caucasian populations. These have included the Maoris of New Zealand (Rose and Prior, 1963), Filipinos in Hawaii and Alaska (Decker, Lane, and Reynolds, 1962; Healey, Caner, and Decker, 1966a), the Chamorros and Carolinians of the Mariana Islands (Burch, O'Brien, Need, and Kurland, 1966), and occasionally some groups of Chinese (Tsung-Po, 1964) or Malaysians (Burns-Cox, 1964). Other Pacific peoples, such as full-blood Hawaiians and national groups of Japanese, Chinese, Portuguese, and Caucasians living in Hawaii (Healey and others, 1966a; Healey, Caner, Bassett, and Decker, 1966b), as well as the North American Indians (O'Brien, Burch, and Bunim, 1966), have been shown to have serum urate levels comparable with very large groups of Caucasians in the United States of America. Limited surveys of Australians of European origin had suggested that their serum urate concentrations were comparable with those in Europe and North America (Emmerson and Sandilands, 1963), but no information in this regard was available concerning the serum urate concentrations in the Australian Aborigines.

The Aboriginal race is a primitive one, anthropologically distinct from all other races. There is controversy about their origin in that some regard them as comprising a single homogeneous people (Abbie, 1966) while others consider that they have a biracial origin (Morrison, 1967). All agree, however, that the original migration was into north western Australia through the islands of Indonesia. The Aborigines are less pigmented than most other coloured peoples and have a fairly characteristic facial appearance (Fig. 1). In the natural state, the Aborigines are nomads, living on nature as they find it, without permanent housing, agriculture, or

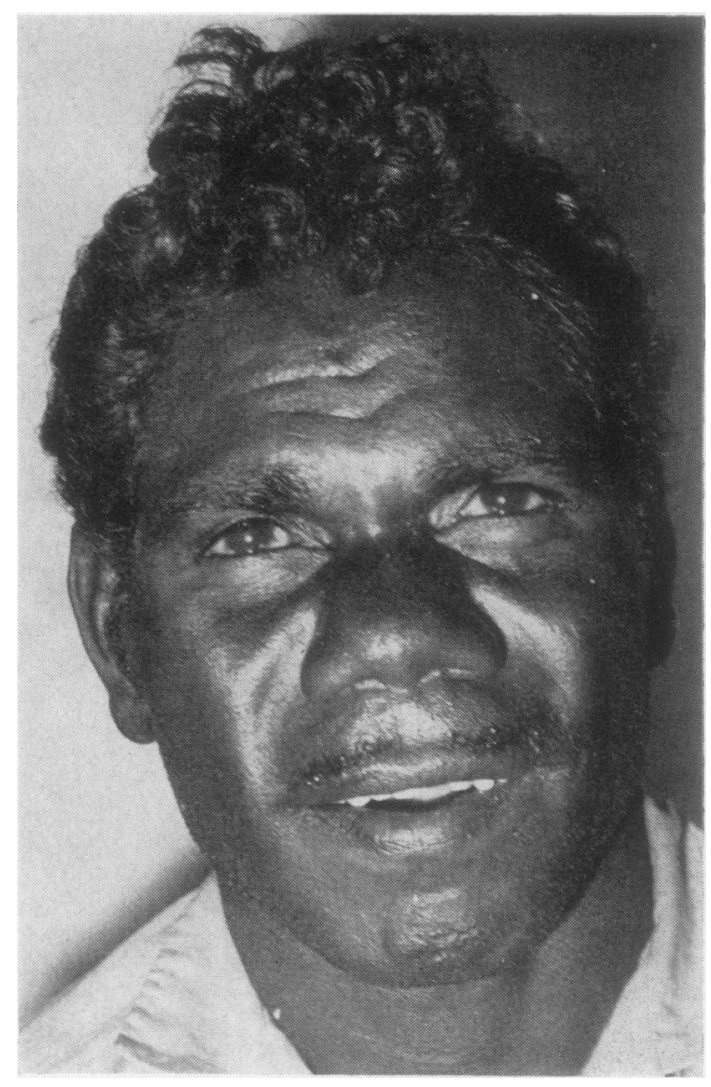

Fig. 1.-Typical Aboriginal face.

animal husbandry (Cook, 1966). The extent of their contact with Western civilization varies greatly, some being fully assimilated into the community, others still living the independent life of their forefathers, while the majority live in mission or government stations or special reserves, where much of their food is supplied. A number who spend a 
part of the year in these settlements return to their hunting nomadic life for the rest of the year and may regularly supplement their European-style diet by hunting. Groups of full-blooded Aborigines large enough for comparison of serum urate levels with those of other ethnic groups could be found only in such settlements, and, of course, the most instructive groups would be ones who had limited contact with European-type civilization. The settlements which best fulfilled these requirements and were reasonably accessible were on the Gulf of Carpentaria, as shown in the accompanying map (Fig. 2).

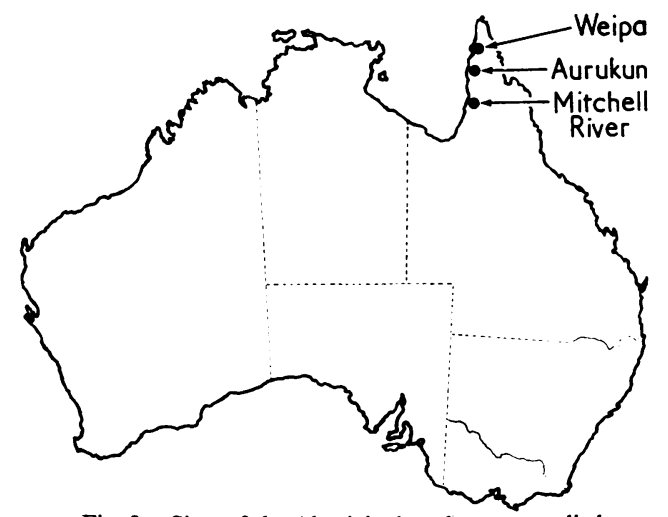

Fig. 2.-Sites of the Aboriginal settlements studied.

\section{Methods}

\section{Subjects Studied}

Sera were obtained from Aborigines in three separate and quite different settlements, Mitchell River, Aurukun, and Weipa. The tribal backgrounds of the Aborigines in this area have been reviewed by Adels and Gajdusek (1963).

Specimens were collected from the Mitchell River settlement in November, 1964, as part of a survey of the extent of virus infections in the area. Selection of patients depended upon their availability and, while not being random, was not biased in any particular direction. Assimilation into the general community is encouraged in this settlement and many of the adult male inhabitants leave periodically to work at nearby cattle stations.

The surveys at Aurukun and Weipa were made a year later as part of a study of the prevalence of rheumatic disease among the Aborigines. All subjects who had their blood sampled were questioned about joint symptoms, were examined clinically for signs of joint disease, and had radiographs taken of their hands. Aurukun is the most isolated settlement and tribal associations there are still strong. All Aborigines present in the settlement at the time agreed to examination and venepuncture. At Weipa, which is close to bauxite fields and where contact with Western civilization is greatest, only the very young and the very old were still in the settlement. The young, and all but four of the older members agreed to venepuncture. Only sera from full-blood Aborigines were included in the present survey.

\section{Diet}

Inhabitants of these settlements receive an issue of food including flour (which is made into damper), porridge, tea, sugar, jam, rice, powdered milk, fruit, and meat. To this may be added biscuits and a variety of canned foods. They can also supplement their diet with food which they can spear, catch, or gather locally, such as fish, crabs, pigs, and wallabies, or sweet potatoes, pawpaws, and mangoes. The more isolated the settlement, the higher the proportion of food which is obtained by these means. No alcohol is consumed at Aurukun, and very little at Mitchell River, but a small amount may be taken in Weipa because of its proximity to a European type of community.

\section{Laboratory Techniques}

After collection, blood was allowed to clot and the serum, removed without centrifugation, was kept at $0-4^{\circ} \mathrm{C}$. for from 48 to 72 hours, after which it was stored in a deep freeze at $-18^{\circ} \mathrm{C}$. until analysis. The serum urate concentration was estimated by the spectrophotometric uricase method (Liddle, Seegmiller, and Laster, 1959) using a Gilford digital absorbance indicator which is able to record absorbance linearly up to 3.000 O.D. units, thus enabling sera with high absorbance values to be assayed directly without the need to vary the blank. 70 per cent. of the sera were analysed in duplicate, the standard deviation of the method

$$
\pm \sqrt{\frac{\text { sum (difference between duplicates) }}{2 \text { (numbers of pairs) }}}
$$

on these 180 sera being $\pm 0.16 \mathrm{mg} . / 100 \mathrm{ml}$. On 170 of these sera, in which the difference was least, the standard deviation was $\pm 0 \cdot 11 \mathrm{mg}$. $/ 100 \mathrm{ml}$, which is comparable with the $\pm 0.1 \mathrm{mg} . / 100 \mathrm{ml}$. achieved on occasion by Mikkelsen, Dodge, and Valkenburg (1965).

\section{Reference Population}

The population chosen for comparison was the Tecumseh, Michigan, population reported by Mikkelsen and others (1965). This was chosen because it was one of the largest groups reported and because the same biochemical technique of urate estimation was used. Their results were also comparable with those obtained for other groups (Hauge and Harvald, 1955; Stetten and Hearon, 1959; Popert and Hewitt, 1962; Hall, Barry, Dawber, and McNamara, 1967). This method of urate estimation depends upon the inherent absorbance of urate in the ultraviolet wavelength and the change which occurs when the urate is destroyed by the action of excess uricase. Any variations between laboratories should thus be minimal and would be most likely to be related to minor technical differences or to the calibration of the spectrophotometer. 
In order to compare the results for the two laboratories, therefore, and through the courtesy of $\mathrm{Dr}$ W. M. Mikkelsen of the University of Michigan, 25 sera were sent from Michigan to Queensland and the urate concentrations estimated. The mean value obtained on these sera in Queensland was $4 \cdot 7 \pm 2.5 \mathrm{mg} . / 100 \mathrm{ml}$. while that obtained in Michigan was $5 \cdot 2 \pm 2.9 \mathrm{mg}$./ $100 \mathrm{ml}$. The mean and standard deviation of the individual differences between the Michigan and Queensland results (subtracting the latter from the former) was $0 \cdot 38 \pm 0 \cdot 8$. The reason for this difference is not fully explained, although it is probably accounted for by variables in storage, thawing, and refreezing, the time of assay, and the different spectrophotometers used.

\section{Results}

Relationship between the Serum Urate Concentration and Sex or Age

As shown in Tables I, II, and III, the significantly higher serum urate concentration in the male, which has been consistently reported in all racial groups studied throughout the world, was also present in the Aboriginal. The relationships between the serum urate and age for the two sexes from the Mitchell River, Aurukun, and Weipa settlements are shown in Table I. For the male groups from
Mitchell River and Aurukun, where all were over 20 years of age, there was no correlation between serum urate and age. In Weipa, the only settlement where people under 20 years were studied and where the mean age of the males studied was 9.4 years, there was a significant regression of urate on age similar to that shown for American Caucasians in this age and sex group by Mikkelson and others (1965). For the female groups, a highly significant correlation of serum urate with age was demonstrated at Aurukun and Weipa. This was not is demonstrated in the Mitchell River group, probably $\vec{\circ}$ because of the small numbers involved. When subjects of 20 years of age or more were studied, no differences were found between the serum urate values in both sexes for the three different settlements of Mitchell River, Aurukun and Weipa. The values for the three settlements could thus be iv validly pooled and, because of their common $\vec{G}$ proximity to the Gulf of Carpentaria, were then referred to as values for the Carpentaria Aborigines.

Relationship between Serum Urate Concentration and Height, Weight, and Surface Area of Body

Data in relation to height and weight were available only for the group from the Aurukun mission

TABLE I

RELATIONSHIP OF SERUM URATE WITH AGE IN AUSTRALIAN ABORIGINAL GROUPS

\begin{tabular}{|c|c|c|c|c|c|c|c|c|}
\hline Settlement & Sex & $\begin{array}{l}\text { Number } \\
\text { of } \\
\text { Subjects }\end{array}$ & $\begin{array}{l}\text { Age } \\
\text { Range } \\
\text { (yrs) }\end{array}$ & $\begin{array}{c}\text { Mean Serum Urate } \\
\text { (mg./100 ml.) } \\
\pm \text { S.D. }\end{array}$ & $\begin{array}{c}\text { Mean Age } \\
\text { (yrs) } \\
\pm \text { S.D. }\end{array}$ & $\begin{array}{c}\text { Slope of Regression } \\
\text { of Urate on Age } \\
\pm \text { S.D. }\end{array}$ & $r$ & Significance \\
\hline Mitchell River & $\underset{\mathbf{F}}{\mathbf{M}}$ & $\begin{array}{l}27 \\
16\end{array}$ & $\begin{array}{l}20-98 \\
20-80\end{array}$ & $\begin{array}{l}5.47 \pm 1.000 \\
4.51 \pm 0.867\end{array}$ & $\begin{array}{l}43 \cdot 3 \pm 15 \cdot 35 \\
51 \cdot 0 \pm 16 \cdot 71\end{array}$ & $\begin{array}{l}0.00004 \pm 0.014 \\
0.0115 \pm 0.0135\end{array}$ & $\begin{array}{l}0 \cdot 0005 \\
0 \cdot 221\end{array}$ & NS \\
\hline Aurukun & $\underset{\mathbf{M}}{\mathbf{F}}$ & $\begin{array}{r}82 \\
135\end{array}$ & $\begin{array}{l}20-75 \\
20-70\end{array}$ & $\begin{array}{l}6 \cdot 03 \pm 1 \cdot 247 \\
4 \cdot 78 \pm 1 \cdot 225\end{array}$ & $\begin{array}{l}42 \cdot 8 \pm 15 \cdot 66 \\
43 \cdot 3 \pm 15 \cdot 27\end{array}$ & $\begin{array}{l}0.0048 \\
0.0190 \pm 0.0089 \\
\pm 0.0068\end{array}$ & $\begin{array}{l}0 \cdot 06 \\
0 \cdot 24\end{array}$ & $P<\stackrel{\text { NS }}{<0.01}$ \\
\hline Weipa & $\mathbf{F}$ & $\begin{array}{r}23 \\
3 \\
20 \\
43 \\
19 \\
24\end{array}$ & $\begin{array}{c}2-54 \\
\text { Over 20 } \\
\text { Under } 20 \\
2-40 \\
\text { Over } 20 \\
\text { Under } 20\end{array}$ & $\begin{array}{l}4 \cdot 50 \pm 1 \cdot 026 \\
5 \cdot 27 \pm 1 \cdot 710 \\
4 \cdot 40 \pm 0 \cdot 898 \\
4 \cdot 59 \pm 1 \cdot 154 \\
5 \cdot 24 \pm 1 \cdot 363 \\
4 \cdot 07 \pm 0.591\end{array}$ & $\begin{array}{r}9.4 \pm 10 \cdot 71 \\
34.0 \pm 8 \cdot 72 \\
5.7 \pm 3 \cdot 84 \\
20.7 \pm 16.61 \\
36.1 \pm 12.72 \\
8.6 \pm 5.40\end{array}$ & $\begin{array}{ll}0.0428 & \pm 0.0187 \\
0.1921 & \pm 0.0395 \\
0.0498 & \pm 0.0538 \\
0.0433 & \pm 0.0085 \\
0.0499 & \pm 0.0230 \\
0.0258 & \pm 0.0227\end{array}$ & $\begin{array}{l}0 \cdot 45 \\
0 \cdot 98 \\
0 \cdot 21 \\
0 \cdot 62 \\
0 \cdot 465 \\
0 \cdot 236\end{array}$ & $\begin{array}{l}\mathbf{P}<0.05 \\
\mathbf{P}<\mathbf{0 . 0 1} \\
\mathbf{N S} \\
\mathbf{P}<\mathbf{0 . 0 1} \\
\mathbf{P}<\mathbf{0 . 0 5} \\
\mathbf{N S}\end{array}$ \\
\hline
\end{tabular}

TABLE II

MEAN VALUES AND CORRELATIONS BETWEEN SERUM URATE CONCENTRATIONS AND AGE, HEIGHT, WEIGHT, AND SURFACE AREA IN ADULT AURUKUN ABORIGINALS

\begin{tabular}{|c|c|c|c|c|c|}
\hline Sex & $\begin{array}{c}\text { Number } \\
\text { of Subjects* }\end{array}$ & Parameter & Mean \pm S.D. & $\begin{array}{l}\text { Correlation } \\
\text { with Serum Urate }\end{array}$ & $\begin{array}{c}\text { Correlation } \\
\text { with Age }\end{array}$ \\
\hline Male & 79 & $\begin{array}{l}\text { Serum Urate (mg./100 ml.) } \\
\text { Age (yrs) } \\
\text { Height (in.) } \\
\text { Weight (lb.) } \\
\left.\text { Surface Area (m. }{ }^{2}\right)\end{array}$ & $\begin{array}{c}6 \cdot 01 \pm 1 \cdot 20 \\
43 \cdot 3 \pm 15 \cdot 7 \\
67 \cdot 2 \pm 2 \cdot 6 \\
126 \cdot 8 \pm 19 \cdot 1 \\
1 \cdot 67 \pm 0.13\end{array}$ & $\begin{array}{r}-0.026 \\
-0.097 \\
+0.009 \\
-0.032\end{array}$ & $\begin{array}{l}-0 \cdot 206 \\
-0 \cdot 072 \\
-0 \cdot 135\end{array}$ \\
\hline Female & 133 & $\begin{array}{l}\text { Serum Urate }(\mathrm{mg} . / 100 \mathrm{ml} .) \\
\text { Age (yrs) } \\
\text { Height (in.) } \\
\text { Weight (lb.) } \\
\left.\text { Surface Area (m. }{ }^{2}\right)\end{array}$ & $\begin{array}{c}4 \cdot 77 \pm 1 \cdot 20 \\
43 \cdot 3 \pm 15 \cdot 2 \\
63 \cdot 0 \pm 2 \cdot 4 \\
107 \cdot 1 \pm 20 \cdot 6 \\
1 \cdot 47 \pm 0 \cdot 13\end{array}$ & $\begin{array}{l}+0.221(P<0.05) \\
+0.050 \\
+0.171(P<0.05) \\
+0.142\end{array}$ & $\begin{array}{l}-0.256(P<0.01) \\
-0.123 \\
-0.176(P<0.05)\end{array}$ \\
\hline
\end{tabular}

*Data on height and weight were not available on three males and two females for whom data on serum urate and age were available. 
who were all 20 years of age or more. The mean values together with the correlation coefficients for the two sexes are shown in Table II.

In eighty males, no significant correlations were found between the serum urate and either height, weight, or surface area, and none of these parameters was of significant value in the prediction of the serum urate.

In 133 females, on the other hand, in whom there was a significant regression of serum urate on age, it was found that age accounted for some 5 per cent. of the variability in the serum urate level. There was also a significant regression with weight which accounted for an additional 4 per cent. of the variability in the serum urate. Relationships with height and surface area were not significant. Weight was not significantly correlated with age, and the significant correlation between weight and serum urate was additional to the effect of age.

It is of interest that the weights of both men and women fell into the range of those recently considered desirable for persons of small frame in the United States of America (Halpern, Glenn, and Goodhart, 1960).

\section{Comparison between Serum Urate Concentrations in Aborigines with Those in Caucasians}

Mean values for the serum urate concentrations in Carpentaria Aborigines were calculated for each sex and age group. Ten-year groupings, rather than the 5-year groupings originally reported for the Tecumseh survey, were chosen to provide Aboriginal groups of sufficient size for statistical analysis. These values, together with comparable figures obtained in the Tecumseh study, are shown in Fig. 3. In all groups, the mean urate concentration was higher in the Aborigines, although statistical significance was reached only in some of the groupings. Because the number under the age of 20 years was so small, the overall comparison for each

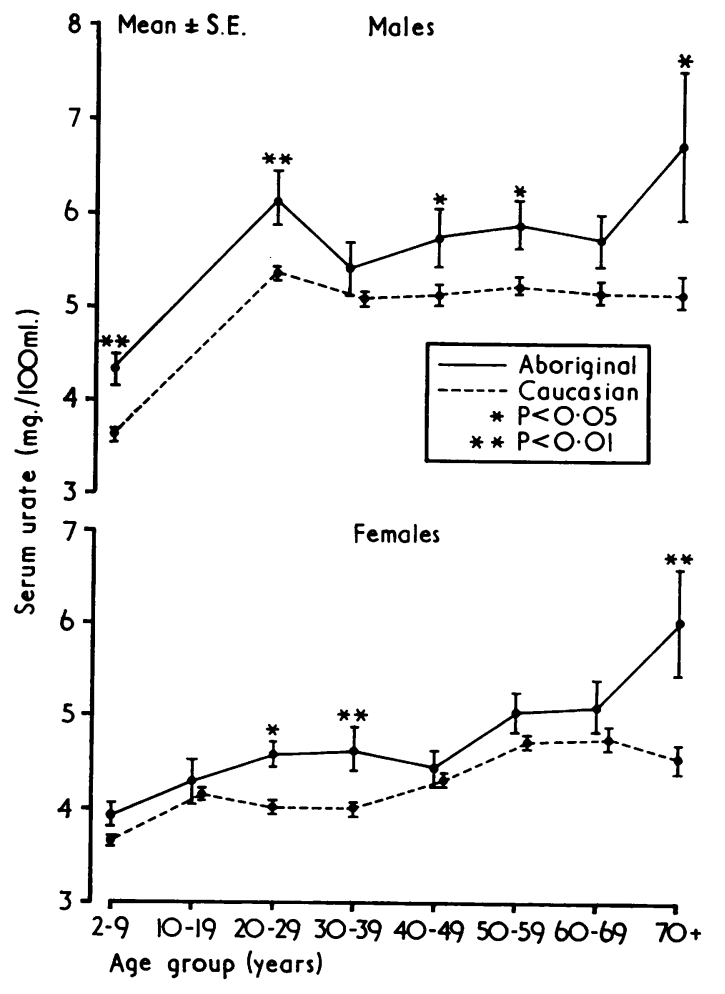

Fig. 3.-Comparison of mean serum urate concentrations for each age group in Aboriginal and Caucasian populations.

sex was limited to persons aged 20 years and over, and this revealed a significantly higher serum urate level in the Carpentaria Aborigines than in the Caucasian group (Table III). Age adjustment, undertaken in females because of the significant regression of serum urate with age already demonstrated in this group, was carried out by the analysis of covariance technique. A separate analysis was also undertaken to compare the Aurukun group

TABLE III

COMPARISON BETWEEN SERUM URATE CONCENTRATIONS IN ABORIGINALS OVER 20 YEARS OF AGE WITH THOSE IN A CAUCASIAN GROUP AT TECUMSEH, MICHIGAN, BY SEX

\begin{tabular}{|c|c|c|c|c|c|c|c|c|c|c|}
\hline \multirow{2}{*}{$\begin{array}{l}\text { Sex } \\
\text { Group }\end{array}$} & \multicolumn{5}{|c|}{ Male } & \multicolumn{5}{|c|}{ Female } \\
\hline & $\begin{array}{c}\text { No. } \\
\text { of } \\
\text { Subjects }\end{array}$ & $\begin{array}{l}\text { Mean } \\
\text { Serum } \\
\text { Urate } \\
\text { (mg./100 ml.) } \\
\text { 土S.D. }\end{array}$ & $\begin{array}{l}\text { Difference } \\
\text { from } \\
\text { Caucasian } \\
\text { Mean }\end{array}$ & $t$ & $\mathbf{P}$ & $\begin{array}{c}\text { No. } \\
\text { of } \\
\text { Subjects }\end{array}$ & $\begin{array}{l}\text { Mean } \\
\text { Serum } \\
\text { Urate } \\
\text { (mg./100 ml.) } \\
\pm \text { S.D. }\end{array}$ & $\begin{array}{l}\text { Difference } \\
\text { from } \\
\text { Caucasian } \\
\text { Mean (age } \\
\text { adjusted) }\end{array}$ & $t$ & $\mathbf{P}$ \\
\hline Caucasian & 1,917 & $5 \cdot 23 \pm 1 \cdot 329$ & & & & 2,039 & $4 \cdot 26 \pm 1 \cdot 197$ & & & \\
\hline $\begin{array}{l}\text { Carpentaria } \\
\text { Aboriginal }\end{array}$ & 112 & $5 \cdot 87 \pm 1 \cdot 239$ & $0 \cdot 64$ & $5 \cdot 0$ & $<0.001$ & 170 & $4 \cdot 80 \pm 1 \cdot 218$ & 0.49 & $5 \cdot 3$ & $<0.001$ \\
\hline $\begin{array}{l}\text { Aurukun } \\
\text { Aboriginal }\end{array}$ & 82 & $6 \cdot 03 \pm 1 \cdot 247$ & $0 \cdot 80$ & $5 \cdot 3$ & $<0.001$ & 135 & $4 \cdot 78 \pm 1 \cdot 225$ & $0 \cdot 46$ & $4 \cdot 4$ & $<0.001$ \\
\hline
\end{tabular}


alone with the Tecumseh group. This was because the Aurukun population was the largest, the most homogeneous, and the most isolated group.

Only minor differences from the results for the whole group of Carpentaria Aborigines were revealed for the various 10 -year groupings. The overall results for the over 20-year age group and the comparison with the Tecumseh group of similar age range were again similar to those found for the Carpentaria Aborigines as a whole (Table III).

\section{Discussion}

The serum urate level in health is determined by a variety of inherited and environmental factors. The most important intrinsic factors are the genetic control of urate production and the renal excretion of urate, and these are probably also modified by age and sex. Of the many environmental factors, the most important seem to be the type of diet, the regularity of alcohol consumption, and physical activity. Correlation between the serum urate and weight or surface area may thus reflect both genetic and acquired factors. The rise in the serum urate at puberty in males and at the menopause in females, as demonstrated most clearly in American Caucasians by Mikkelsen and others (1965), was also present in the Australian Aboriginal. This necessitated the consideration of the Aboriginal figures in groups according to age and sex, and age correction of the overall values for females.

Hyperuricaemia has often been associated with obesity. O'Brien and others (1966), studying the American Indians, found a high correlation between serum urate and weight, and an even greater correlation with surface area. Burch and others (1966) found a similar relationship with body size in the inhabitants of the Mariana Islands, and Kriźek (1966) has shown that obese Europeans have higher serum urate levels than the non-obese. However, no correlation between the serum urate and height, weight, or surface area was present in the male Aboriginal, and, although there was some correlation between serum urate and weight in the female, this made only a very slight contribution to the serum urate level. Factors other than body build also appear to be operating, however, because whereas the Maoris as a group are both obese and hyperuricaemic (Prior, Rose, Harvey and Davidson, 1966) the Hawaiians, who are also Polynesian, tend to be obese but are not hyperuricaemic (Healey and others, 1966b). The Australian Aboriginal, moreover, is rather lean and below the weight considered desirable for Caucasians. His relative hyperuricaemia is thus not attributable to body build or obesity and is unlikely to be due to overnutrition and other dietary factors. It would appear that the differences in serum urate concentrations demonstrated between different races are not entirely explicable by differences in body size and configuration.

Socio-economic variables have also been considered as possible factors affecting the serum urate. Correlations between the serum urate and achieved social class as reflected by occupation, education, and tests of intelligence have been reported (Stetten and Hearon, 1959; Dunn, Brooks, Mausner, Rodnan, and Cobb, 1963; Montoye, Faulkner, Dodge, Mikkelsen, Willis, and Block, 1967), but these factors again can hardly explain the hyperuricaemia present in the Aboriginal. The higher serum urate in the Aboriginal might also be due to associated renal disease or to the form of chronic renal disease which was peculiarly common in Queensland, chronic lead nephropathy. However, no greater incidence of renal disease has been described in Aborigines, and the lead exposure which commonly produced chronic lead nephropathy is a disease of civilization in a tropical climate with children exposed to weathered lead paint, and it would be unusual for an Aboriginal to have lived in a house which was painted.

Despite the higher mean urate in the Aboriginal than in the Caucasian, clinical attacks of gouty arthritis are extremely rare. Enquiry from the Royal Flying Doctor Service and many Aboriginal settlement hospitals throughout Australia has not so far revealed a single case of gout in an Australian Aboriginal. The hyperuricaemia in Maoris on the other hand is associated with a high incidence of clinical gout. However, the mean serum urate in Maori males is over $7.0 \mathrm{mg} . / 100 \mathrm{ml}$. which is considerably higher than the $5.9 \mathrm{mg} . / 100 \mathrm{ml}$. found for Aboriginal males. Thus, the different incidence of clinical gout probably occurs because the serum urate level in the Aboriginal, though relatively higher than in Caucasians, is still not high enough to induce attacks of gouty arthritis.

Thus most of the known associations do not account for the higher mean serum urate in the Aboriginal, and no explanation can be offered for this finding at this time. Further studies of Aboriginal groups in other parts of Australia, of more primitive tribes and of groups fully assimilated into the whole community, may eventually elucidate the situation further. On present evidence, however, it would seem that the most likely factor responsible for the higher serum urate levels in the Aboriginal is racial. 


\section{Summary}

The serum urate concentrations in a group of Australian Aborigines living near the Gulf of Carpentaria have been shown to be significantly greater than those in a control Caucasian population. No factors other than racial have been found to account for the difference.

The authors are indebted to the Mayne Research Fund of the University of Queensland for laboratory facilities and for the provision of a Medical Research Fellowship to enable one of us (W.D.) to undertake the survey. They are also grateful to the Australian Rheumatism Council for support, to the Queensland Department of Health for its cooperation, to the Superintendent and nursing Sisters at Aurukun and Weipa for their assistance, to the Curator of Anthropology of the South Australian Museum for the Aboriginal photograph, and to the Medical School Computer Facility of the University of Pennsylvania (N.I.H. grant No. FR15) for the analysis.

\section{REFERENCES}

Abbie, A. A. (1966). Homo (Göttingen), 17, 73 (The anthropological status of Australian Aborigines).

Adels, B. R., and Gajdusek, D. C. (1963). Amer. J. Hyg., 77, 317 (Survey of measles patterns in New Guinea. Micronesia and Australia).

Burch, T. A., O'Brien, W. M., Need, R., and Kurland, L. T. (1966). Ann. rheum. Dis., 25, 114 (Hyperuricaemia and gout in the Mariana Islands).

Burns-Cox, C. J. (1964). Med. J. Malaya, 19, 25 (Thirty-three cases of acute arthritis in Sabah).

Cook, C. E. (1966). Med. J. Aust., 1, 559 (Medicine and the Australian Aboriginal: a century of contact in the Northern Territory).

Decker, J. L., Lane, J. J., and Reynolds, W. E. (1962). Arthr. and Rheum., 5, 144 (Hyperuricaemia in a male Filipino population).

Dunn, J. P., Brooks, G. W., Mausner, J., Rodnan, G. P., and Cobb, S. (1963). J. Amer. med. Ass., 185,431 (Social class gradient of serum uric acid levels in males).

Emmerson, B. T., and Sandilands, P. (1963). Aust. Ann. Med., 12, 46 (The normal range of plasma urate levels).

Hall, A. P., Barry, P. E., Dawber, T. R., and McNamara, P. M. (1967). Amer. J. Med., 42, 27 (Epidemiology of gout and hyperuricaemia).

Halpern, S. L., Glenn, M. B., and Goodhart, R. S. (1960). J. Amer. med. Ass., 173, 1576 (New heightweight tables).

Hauge, M., and Harvald, B. (1955). Acta med. scand., 152, 247 (Heredity in gout and hyperuricaemia).

Healey, L. A., Caner, J. E. Z., Bassett, D. R., and Decker, J. L. (1966b). J. Amer. med. Ass., 196, 364 (Serum uric acid and obesity in Hawaiians).

Křižek, V. (1966). Ann. rheum. Dis., 25, 456 (Serum uric acid in relation to body weight).

Liddle, L., Seegmiller, J. E., and Laster, L. (1959). J. Lab. clin. Med., 54, 903 (Enzymatic spectrophotometric method for determination of uric acid).

Mikkelsen, W. M., Dodge, H. J., and Valkenburg, H. (1965). Amer. J. Med., 39, 242 (The distribution of serum uric acid values in a population unselected as to gout or hyperuricemia, Tecumseh, Michigan, 1959-1960).

Montoye, H. J., Faulkner, J. A., Dodge, H. J., Mikkelsen, W. M., Willis, P. W., and Block, W. D. (1967). Ann. intern. Med., 66, 838 (Serum uric acid concentration among business executives).

Morrison, J. (1967). Med. J. Aust., 2, 1054 (The biracial origin of the Australian Aborigines).

O'Brien, W. M., Burch, T. A., and Bunim, J. J. (1966). Ann. rheum. Dis., 25, 117 (The genetics of hyperuricaemia in Blackfeet and Pima Indians).

Popert, J., and Hewitt, J. V. (1962). Ibid., 21, 154 (Gout and hyperuricaemia in rural and urban populations).

Prior, I. A. M., Rose, B. S., Harvey, H. P. B., and Davidson, F. (1966). Lancet, 1, 333 (Hyperuricaemia, gout, and diabetic abnormality in Polynesian people).

Rose, B. S., and Prior, I. A. M. (1963). Ann. rheum. Dis., 22, 410 (A survey of rheumatism in a rural New Zealand Maori community).

Stetten, D., Jr., and Hearon, J. Z. (1959). Science, 129, 1737 (Intellectual level measured by army classification battery and serum uric acid concentration).

Tsung-Po, K. (1964). J. Formosa med. Ass., 63, 415 (Gout in the tropical Taiwan). 
La concentration des urates du sérum des aborigènes australiens

RÉSUMÉ

La concentration des urates du sérum chez un groupe d'aborigènes australiens habitant près du Golfe de Carpentarie a été démontrée comme étant beaucoup plus élévée que celle d'une population "temoin" caucasienne. Aucun facteur autre que racial n'a été trouvé pour expliquer cette différence.
Concentraciones de urato sueroso en el aborigen australiano

Sumario

Las concentraciones de urato sueroso en un grupo de aborígenes australianos que viven cerca del Golfo de Carpentaria han revelado ser significativamente más altas que las de una población caucasiana testigo. Se ha comprobado que ningún factor, aparte del racial, explica la diferencia. 